\title{
EPILEPSY AND ORAL HORMONAL CONTRACEPTION-INDIAN PERSPECTIVE
}

\author{
SHRIPAD HEBBAR
}

Department of Obstetrics and Gynaecology, Kasturba Medical College, Manipal University, Manipal, Karnataka

Email: shripad. hebbar@manipal.edu

Received: 10 Dec 2016 Revised and Accepted: 17 Jan 2017

\begin{abstract}
There are about 50 million people with epilepsy in the world and a quarter of them are in the reproductive age group. India alone contributes to $10 \%$ of this fig. Because of the advances in therapeutic drugs, the women affected with epilepsy easily enter into reproductive life. These women like others are highly fertile and frequently need to adopt effective and safe contraceptive measures to avoid unplanned pregnancy. There are several concerns regarding the efficacy and safety of natural methods or barrier methods in women who are taking antiepileptic drugs (AED), failure of which poses a great risk to the affected person because pregnancy can result in exposure of fetus to the teratogenic effect of AEDs and also the hemodynamic changes in pregnancy can lower the plasma concentrations of AED and there can be poor seizure control. Oral hormonal pills are prescribed to epileptic women, not only for birth control but also in certain situations such as polycystic ovaries, irregular menstruation, acne and dysfunctional uterine bleeding. There are major bidirectional interactions between reproductive hormones and antiepileptic drugs which the physician should be aware of while dealing with these women. There are now enough evidence that oral contraceptive pills can reduce the efficacy of AEDs by affecting their metabolism and also AEDs by themselves may affect the contraceptive efficacy of oral pills by different pathways. Though estrogen free hormonal contraception is least likely to be effected by this nature of drug interaction, but still caution should be exercised in drug prescription as progesterone by itself has a lesser contraceptive effect and hence even slighted drug interaction too can lead to contraceptive failure. This extensive review focusses upon potential drug interactions between constituents of various oral pills and anti-epileptic drugs, the formulations available in India with different dosages for oestrogen and newer progestogens with their advantages with a special note on ormeloxifene which is exclusively marketed for birth control in Rural India. Special conditions such as contraception during lactation and emergency contraception for epileptic women are also discussed.
\end{abstract}

Keywords: Oral contraception, Epilepsy, Anti-Epileptic Drugs (AED), Hepatic enzyme induction, Ormeloxifene

(C) 2016 The Authors. Published by Innovare Academic Sciences Pvt Ltd. This is an open access article under the CC BY license (http://creativecommons.org/licenses/by/4. 0/) DOI: http://dx.doi.org/10.22159/ijpps.2017v9i3.16540

\section{INTRODUCTION}

Epilepsy is a common medical disorder which affects both males and females with equal frequency ( $0.5 \%$ each). By 2001 , the number of people with epilepsy was estimated to be 5.5 million in India alone and every year half a million new cases were added to this fig. [1] Because of rapid development in pharmaceutical drugs for control of seizures, many of epileptic children reach reproductive age group and get married. Most of them would require contraception at some point of their reproductive age group and till today hormonal contraception is commonly practiced method today even in epileptics. Women even when not on any oral hormones, likely to exhibit variation in seizure patterns when they are subjected to intense physiological changes in reproductive hormones that occur during puberty, various stages of the menstrual cycle and especially during pregnancy. These changes may further get aggravated when hormonal methods of birth control are advised to them [2, 3].

A Recent study indicates that oral combined pills are prescribed for $17 \%$ of reproductive age women with seizure disorders which is only $8 \%$ less than the general population [4]. Hence it is a common situation for a physician to encounter women on concurrent antiepileptic drugs and oral hormonal contraception. By now, it is known that antiepileptic drugs induce hepatic synthesis of Cytochrome P450. Because of these interactions between antiepileptic drugs (AEDs), the efficacy may get compromised, and health care professionals are bound to give appropriate counseling, various contraceptive choices for safe and foolproof birth control [5]. However, a recent survey indicated that nearly half of the women were poorly informed about these aspects [6]. To make the scenario worst, a large majority of physicians and gynaecologists fail to understand potential drug interactions between AEDs and contraceptive drugs. A contraceptive failure may be the grave situation for epileptic women because not only there is a risk of teratogenicity in the offspring, but also pregnancy may result in poor seizure control and both will have a serious impact on quality of life $[7,8]$.
The incidence of neural tube effect is definitely high if a contraceptive failure occurs in a woman taking AEDs such as Carbamazepine, Valproate, Lamotrigine, Phenobarbital, etc. How exactly AEDs cause teratogenicity is not very clear but postulated to be due to AED-induced folate deficiency. The two important placental proteins, folate receptor protein and Carnitine O-acetyl transferase are likely to be affected adversely by AEDs. Folate receptors play a critical role in mediating placental transport of maternal folate to the fetus. Carnitine $\mathrm{O}$-acetyl transferase that is involved in the transport of carnitine, which is much needed for fetal metabolic functions and tissue development. The binding of the Anti-Epileptic drugs with these crucial proteins makes them inefficient in their routine function thus resulting in Neural Tube Defect [9].

Serum concentration of some of the AEDs, for example, lamotrigine markedly varies during oral pill cycle. During the "pill on" phase (mostly $21 \mathrm{~d}$ in a 28 cycle) lamotrigine level may come down almost by $50 \%$ and poor seizure control may result. Similarly, during "pill free" interval, the level may raise causing lamotrigine toxicity such as dizziness, double vision and lack of coordination. Hence tailoring of dosage is required depending upon the phase of pill intake. This means that treating physician should be aware of various formulations of oral contraceptive pills having different concentration of oestrogen (low dose, standard dose and high dose pills) in them [10].

The main objective of the present review is to understand the twoway interaction between contraceptive agents and AEDs. The other purpose is to highlight the available hormonal contraceptive agents in Indian pharmaceutical market which will serve as a ready reference for drug prescription for women with epilepsy.

The effect of AEDs on the pharmacokinetics of combined OCs

In the past, the combined oral contraceptive pills had very high concentration of ethinyl estradiol ( $>100 \mathrm{mcg}$ ). This high dose was found to be associated with increased incidence of thrombo- 
embolism and stroke. Further research indicated that equal protection could be achieved with reducing ethinylestradiol fraction to less than $50 \mathrm{mcg}$. Though this modification was successful in reducing thrombogenic risks, higher incidence of breakthrough bleeding and pregnancies were reported among women on AEDs. The unplanned pregnancy rates were as high as $25 \%$ due to OC failure [11]. There was a higher incidence of AED-induced teratogenicity [12]. This created interest among researchers to study the interactions between AEDs and OC pills.

Further studies indicated that many of AEDs induce hepatic synthesis of cytochrome P450 (CYP) 3A4, a critical isoenzyme which converts estrogen into biologically inactive hydroxylated metabolites. To some extent, even progesterone metabolism and renal clearance is accelerated by the same enzyme system. The quantum of hepatic enzyme induction also depends upon genetic and environmental factors and hence varies from individual to individual. Studies indicate that resultant decrease plasma levels of active forms of estrogen and progesterone may be as high as $50 \%$ $[13,14]$. But it is difficult to find these associations, and hence an increase in estrogen component at least to $50 \mathrm{mcg}$ is advocated for women on AEDs which causes a reduction in serum levels of female hormones (table 1) to avoid contraceptive failure and unwanted conception. Another possible mechanism by which AEDs may decrease the serum levels of estrogens and progesterone is the elevation of SHBG (serum hormone binding globulin), which binds to the biologically active portion of the circulating estrogen and progestogen and thereby decrease their contraceptive action [15]. There are group of AEDs which may not reduce the efficacy of oral contraceptive pills (table 2), women are warned to report immediately in the event of missed periods, so that potential unwanted pregnancy can be diagnosed immediately and medical termination of pregnancy can be easily done without much risk to the life of the pregnant woman.

The hepatic induction of various enzymes is also required for the metabolism of many of AEDs and their subsequent elimination from the body. CYP3A4 is responsible for the oxidation of old generation AEDs such as carbamazepine, ethosuximide and newer AEDs such as tiagabine and zonisamide. CYP2C9 and CYP2C19 cause oxidation and Nglucosidation of phenytoin and phenobarbitone. Other isoforms of CYP may be implicated in similar processes in conjugation and elimination of valproic acid, felbamate and topiramate. Glucuronyltransferase activation results in conjugation of valproic acid, lamotrigine and oxcarbazepine. $\mathrm{N}$-acetyl transferase may play a role in $\mathrm{N}$-acetylation of zonisamide and thereby enhancing its renal excretion [16].

Table 1: Anti-epileptic drugs (AED) which may reduce efficacy of oral contraceptive pills

\begin{tabular}{|c|c|}
\hline Generic drug & Brand name and manufactures (in bracket) in India \\
\hline Carbamazepine & $\begin{array}{l}\text { ANTILEP [Psycorem], CARBADAC200 [ZydusCadila], CARBAPA-RET [Olcare], CARBASURE [Gentech ], CARBATOL [Torrent], } \\
\text { CARIV [East African], CARIZINE [East West], CARMAZ [Sun], CARMAZKID [Sun], CARMEG [Alembic], CARZEP [Taurus Labs], } \\
\text { CARZINE [East West], CINCAR [Cinerea], CIZETOL [Cipla], CORGONE [Sykocure], EPINIL [Inga], EPIX [Baroda], MAZE [Aarpik], } \\
\text { MAZETOL [AHPL], MAZETOLTAB [AHPL], MEZAPIN [La Pharma], MEZARIL [Reliance], MEZATRIC-ER [Cubit], RISCARB } \\
\text { [Symbiosis], SALICARB [Orchid], SWIZTOL [Ind-Swift], TAZETOL [Gujarat Terce], TEGRITAL [Novartis India], VERSITOL [Micro } \\
\text { Synapse], VERSIZUR [MicroLabs], ZEN [Intas], ZENRETARD [Intas], ZEPCAR [Alkem], ZEPTOL [Sun], ZIGMA [Crescent] }\end{array}$ \\
\hline Felba & Not available in India. Imported as Felbatol $®$ \\
\hline Lamotrigine & $\begin{array}{l}\text { EPITIC [Psycorem], FAVLAM [USV], LAMEPIL [IPCA], LAMETEC [Cipla], LAMEZ-OD [Intas], LAMIDUS [Zydus], LAMITOR-DT } \\
\text { [Torrent], LAMOGIN [FDC], LAMORIG [Unichem], LAMOSYN [Sun], LEMOGEN [Gentec], SYLAM [Sykocure] }\end{array}$ \\
\hline Oxcarbazepine & $\begin{array}{l}\text { ALFOX [Medihealth], CARBAMAC [Macleods], CARBOX [Micro Synapse], MEZALOG [La Pharma], OLEPTAL-600 [Torrent], } \\
\text { OLEPTAL-DT [Torrent], OLEPTAL-OD [Torrent], OXANA [Psycorem], OXANA-SR [Psycorem], OXCARB [Cipla], OXCAZO } \\
\text { [Unichem], OXEP [AHPL], OXEPIN [Mesmer], OXEPTAL [ZydusCadila], OXETOL [Sun], OXILEPTIN [Pfizer], OXINE [Sykocure], } \\
\text { MAZETOL [AHPL], OXMAZETOL-ER [AHPL], OXRATE [Wockhardt], OXZEY [Sunrise], SELZIC [Ranbaxy], TRIOPTAL [Novartis } \\
\text { Pharma], VINLEP [SanofiSynth], ZENOXA [Intas] }\end{array}$ \\
\hline Phenobarbitol & $\begin{array}{l}\text { BARBEE [Ind-Swift], BEETAL [Intas], EPITAN [Reliance], FENOBARB [Samarth], GARDENAL [AHPL], PHENETONE [ Cipla], } \\
\text { PHENOBARB [Intas], SHINOSUN [Sunrise] }\end{array}$ \\
\hline Phenytoin & $\begin{array}{l}\text { CELETOIN [Intas], C-TOIN [USV], DILANTIN [Pfizer], EPICARE [Olcare], EPICENT [Crescent], EPICID [Placid], EPILEPTIN [IDPL], } \\
\text { EPIPRES [Psycorem], EPITAB [East West], EPSOLIN [Zydus], EPTOIN [Abbott], FENTOIN [Sun], GENTOIN [Gentech], M-TOIN } \\
\text { [Medopharm], NEPTOIN [Mankind]], NOFITE [Sunrise], NOFITE JR [Sunrise], NUTOIN [Minova], PHALIN [Molekule], } \\
\text { PHENYKEM [Alkem], PHENYTOIN [Samarth], PHENYTO-S [Anglo French], PHETOIN [Reliance], PNA [Orchid], POLYTOIN } \\
\text { [Symbiosis], SOLPHEN [Ranbaxy], STOIN [Sunrise], TOINEX [Invision], XETOIN [Medihealth] }\end{array}$ \\
\hline Primidone & Mysoline [Abbott Healthcare] \\
\hline Rufinamide & Not available in India. Imported as Banzel@ \\
\hline Topiramate & $\begin{array}{l}\text { EPIMATE [Psycorem], EPITOME [Triton], EPITOP [Micro Synchro], NEXTOP [Torrent], NUROMATE [Invision], TOPAMAC } \\
\text { [Janssen], TOPAMATE [Cipla], TOPAMED [Mesmer], TOPAZ [Intas], TOPEX [Cipla], TOPIRAIN [Unichem], TOPIRAM [Zydus], } \\
\text { TOPIRATE [Pulse], TOPIROL [Sun], TOPIVAL [East West], TOPRISUN [Sunrise], TOPSE [Crescent] }\end{array}$ \\
\hline
\end{tabular}

\section{Effect of OC Pills on metabolism of lamotrigine}

The drug interaction between lamotrigine and combined pills need special mention. Estrogens and progestogens are known to induce hepatic synthesis of uridine diphosphate glucuronosyltransferase enzyme. This results in increased conjugation of lamotrigine by glucoridation and subsequent renal excretion [17-19]. This is a wellknown phenomenon during pregnancy wherein both levels of estrogen and progesterone increase and simultaneously serum lamotrigine level decrease and the patient may require a steep increase in the daily dosage [10]. In a retrospective case series study involving 56 women, four women had a recurrence of seizures after receiving oral contraceptive pills (OCP) due to a decrease in serum lamotrigine levels. The OCP users had mean serum concentration of 13 micromoles per litre (range 2 to 29 ) compared to 28 micromoles per liter (range 7 to 69) in non-users.

Similarly, the sudden rise in lamotrigine levels occurred when one of the subjects stopped taking pills. This lead to increased AED-induced side effects such as nausea, dizziness and diplopia [20]. The extent of fall in serum lamotrigine has been extensively studied. In one study, concurrent administration of oral hormonal pills caused $39 \%$ reduction in maximum concentration and $52 \%$ decrease in area under the curve (AUC). At the same, a modest decrease in serum levenorgestrel levels was also noticed, but there was no change in serum ethinylestradiol concentrations. However, the suppression of HPO axis was adequate and there was no need to switch over to high dose OC pills [21].

Hence it is advisable to increase the dose of lamotrigine dose, especially when it is used a sole drug (monotherapy). At the same, the patients should be warned about lamotrigine toxicity symptoms that may occur during pill free period (usually OC pills are stopped during the late luteal phase in order to induce withdrawal bleeding to mimic normal menstruation) [22]. Thus at present, it is recommended to increase the daily dose of lamotrigine when the woman has been prescribed oral contraception and the dose has to be brought back to earlier prescribed strength or even lesser during pill free interval [23]. As lamotrigine does not affect estrogen metabolism, pills containing $30 \mathrm{mcg}$ of ethinylestradiol are quite good enough for the contraceptive purpose. 
Table 2: Anti-epileptic drugs (AED) which may not reduce efficacy of oral contraceptive pills

\begin{tabular}{|c|c|}
\hline Generic drug & Brand name and manufactures (in bracket) in India \\
\hline Acetazolamide & $\begin{array}{l}\text { ACETAMIDE [Micro Vision], ACETAMIN [Time Drugs], ACETARIV [East African], AVVA [Intas], IOPAR-SR [FDC], SYNOMAX } \\
\text { [SynthoPharma], ZOLAMIDE [Shalaks] }\end{array}$ \\
\hline Clonazepam & $\begin{array}{l}\text { CLEZ [Zodak], CLON [Mediez], CLONAFIT [Mankind], CLONAJI [Shasun], CLONAMED [Medihealth], CLONAPAX [Reliance], } \\
\text { CLONAZER [Active HC], CLONIR [Shirr], CLONOPAM [Molekule], CLONOZEB [Care Pharma], CLOTWEET [Tweet India], CLOZIPAM } \\
\text { [World Wide], COPAM [Constant], CZAP [Biosans], EMINAZ [Emenox], EPCON [La Pharma], FREEDO [Bayu], HICOL [Biochemix], } \\
\text { INCLOZ [Intel Pharma], JASOCALM [Jasco], LOGEN [Gentech HC], LONACEN [USV], LONAZEP [Sun], LONIN [Chemo], MELZAP } \\
\text { [Alkem], NAZ [Divine], NAZA-ES [Rhine Biogenics], NOREP [Mankind], ONZ [Symbiosis], OZEPAM [IPCA], PECALM-MD [Peerage], } \\
\text { PETRIL [Micro Synapse], QP-ZEP [Quality], REVOZIP [ Dycine ], RISPAM [Symbiosis], RIVOTRIL [AHPL], RIVOTRIL [AHPL], SEZOLEP } \\
\text { [Wockhardt], SOMNOLEX [ Somnogen], SOMNOTRIL [Somnogen], TECLOZEP [ Gokul], ZAPIZ [ Intas ], ZEMED [Osmed] }\end{array}$ \\
\hline Ethos & Zarontin [Parke-Davis] \\
\hline Gabap & $\begin{array}{l}\text { ALCOBAL [Obsurge], CERENEURON [Biosciences], COBAGEN [Macleods], DEURO-M [Dhara], DOLONEURON [Pulse], GABAMEC } \\
\text { [Albin], GABAMIN [Macleods], GABANEURON [Aristo], GABANTIN [Sun], GABATA [Alkem], GABATIN [Neon Labs], GABATOR } \\
\text { [Torrent], GABAZ [Ritz Pharma], GABIL [Biocon], GABTIN [Johnlee], GABY [Siomond], GAME [Dyota], GENTIN [Psycorem], } \\
\text { GOBEN [CMGBT], INDCOBAL [Ind Biosciences], PROGABA [Mesmer], WINTIN [Zee Lab], }\end{array}$ \\
\hline Lacosamide & LACASA [Zydus], LACOPSY [Cipla], LACOSAM [Torrent], LACOSET [Sun], SEIZGARD [UCB] \\
\hline Levetiracetam & $\begin{array}{l}\text { EPICTAL [IPCA], EPILIVE [Lupin)], KEPPRA [UCB], KEPPRA INF [UCB], LENERVE [East West], LEVACETAM [Micro Labs], } \\
\text { LEVECETAM [Psycorem], LEVEFREE [Pfizer], LEVEMEX [Mesmer], LEVEMEX-OD [Mesmer], LEVEPSY [Cipla], LEVERA [Intas], } \\
\text { LEVERON [Macleods], LEVESAM [AHPL], LEVETEE [Tweet India], LEVEXX [ZydusCadila], LEVILEX [Abbott], LEVIPIL [Sun], } \\
\text { LEVRACET [Emenox], LEVROXA [Ranbaxy], LEVTAM [Unichem], LITEM [Johnlee], SEIZ-FREE [USV], TORLEVA [Torrent], } \\
\text { TORLEVA-XR [Torrent], VITISUN [Sunrise] }\end{array}$ \\
\hline Pregabalin & $\begin{array}{l}\text { LYRICA [Pfizer], LYRIMAX [Stuvet], MAXGALIN [Sun], NERVMAX [Alkem], NERVO [Invomed], NERVOMAC-P [Medihealth], } \\
\text { PREGEB [Torrent], PREGICOB [Intra] }\end{array}$ \\
\hline Valproic Acid & $\begin{array}{l}\text { ENCORATE[ Sun], EPIVAL[ Sun], EPSOVAL[ La Pharma], LEEPORATE[ Johnlee], MACORATE[ Sun], MANOVAL[ Orchid], } \\
\text { MEGACOT[ Psycorem], SORIC[ Sykocure], TORVATE[ Torrent], VAL[ Baroda], VALANCE SOLN[ AHPL], VALCIP[ Cipla], }\end{array}$ \\
\hline Tiagabine & Not available in India. Imported as Gabitril $®$ \\
\hline Vigabatrine & Vegarin [Taj] \\
\hline Zonisamide & ZONEGRAN [Eisai], ZONICARE [Abbott], ZONIMID [Intas], ZONISEP [Sun], ZONIT [Torrent] \\
\hline
\end{tabular}

\section{Oral contraceptive drugs available in India}

Currently, two types of oral pills are available in India. These include monophasic pills and multiphasic pills (table $3-5$ ). In monophasic pills the combination of estrogen and progesterone is constant though out the cycle, whereas in multiphasic pills the concentration varies in different parts of menstrual cycle so as to mimic hormonal changes that occur in the normal menstrual cycle. Whatever the type, in India most of the pills contain ethinylestradiol as an estrogenic component, however, the type of progesterone varies from brand to brand (for example, norgestrel, levonorgestrel, desogestrel, cyproterone acetate and drospirenone). The cost of medication increases depending upon the type of progesterone used (less than 100 INR for levonorgestrel/norgestrel, 100 to 200 INR for desogestrel, 200 to 300 INR for cyproterone and above 300 INR for drospirenone-containing pills). The concentration of ethinylestradiol varies from $20 \mathrm{mcg}$ to $50 \mathrm{mcg}$, depending upon whether the pill is low dose, standard dose or high dose.

Table 3: Standard dose OC pills available in India

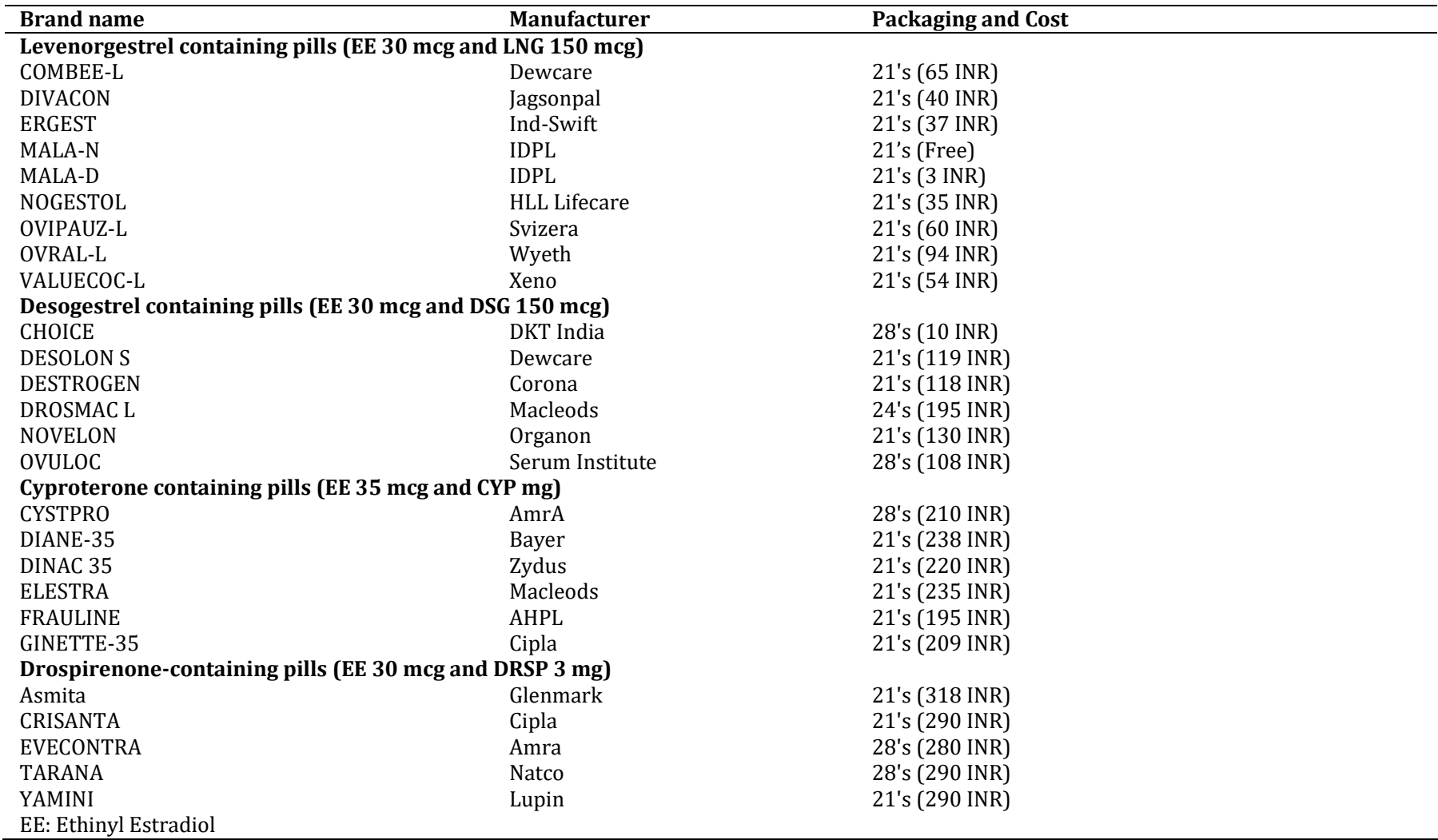


Because of government prize regulation, standard dose OC pills are made affordable for all class of society, whereas low dose formulations though contain less amount of ethinylestradiol are sold at higher prizes. The government of India has heavily subsidised two brands; Mala D (3 INR per strip) and Mala N (available free).

Multiphasic pills are less popular in India. Triquilar is a low dose triphasicOCpill and is available in selected cities. Each pack contains 6 tabs of levonorgestrel $50 \mathrm{mcg}$, ethinylestradiol $30 \mathrm{mcg}$, 5 tabs of levonorgestrel $75 \mathrm{mcg}$, ethinylestradiol $40 \mathrm{mcg}$ and 10 tabs of levonorgestrel $125 \mathrm{mcg}$, ethinylestradiol $30 \mathrm{mcg}$. These tablets are taken from 5 th day of menses sequentially.
Most of the pills are sold like 21 or 24 tablets pack, which are supposed to be taken as one tablet per day from the second day of menstrual cycle till they get over.

Soon after, the withdrawal bleeding occurs within few days and from the next 2 nd day of withdrawal bleeding, the same cycle will continue till the contraception is desired.

Some formulations add 7 tablets of ferrous salts at the end of 21 tablets which are meant to be taken after the main course is over, the advantages being the continuous usage of drugs without any pill free interval and some protection against iron deficiency anemia.

Table 4: Low dose OC pills available in India

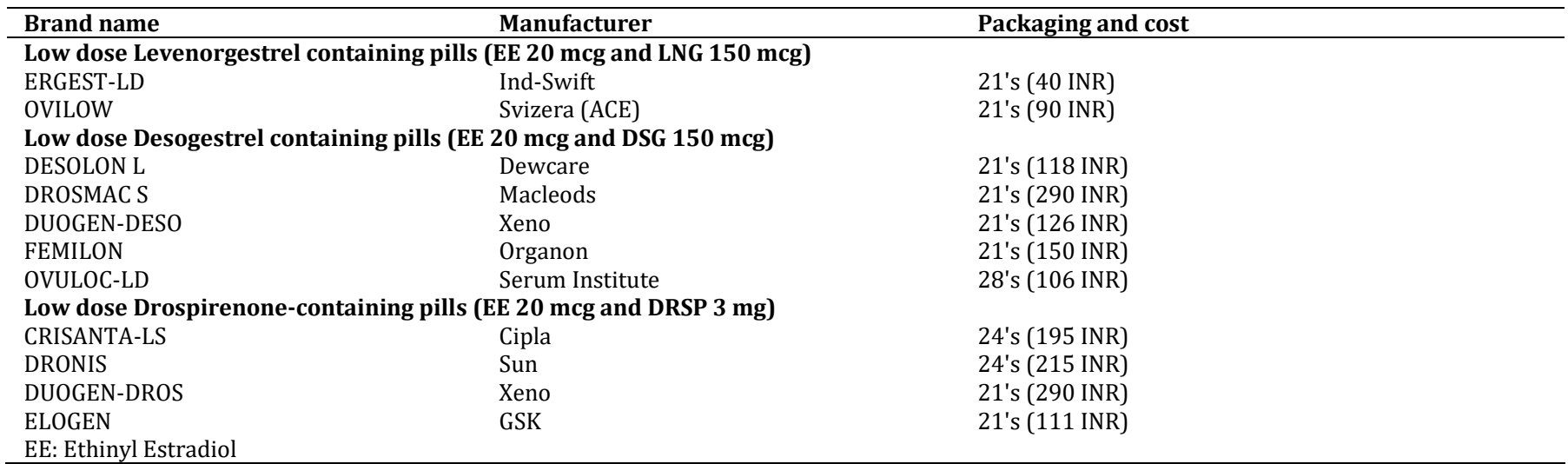

Estrogen-containing pills may interfere with the amount of milk produced during lactation. Progesterone only pills, also known as lactational or mini-pills are popular in India and they are meant to be taken continuously without a break till the woman requires birth control. Now in India, there is an increased awareness among the teenagers about emergency contraceptive pills. Prior to 2005, they were available only by prescription, but now the government has made it available over the counter and annually more than 3 million pills are sold in India annually.
Until 2005 Emergency Contraceptive Pill was relatively scarce because it was available only by prescription, but since then the government has made it available over the counter, which means that it can be bought without a prescription.

With this change, more than 200,000 emergency pills are sold in India every month. They contain $1.5 \mathrm{mg}$ of levonorgestrel and should be taken as soon as possible following unprotected intercourse, but no longer than $72 \mathrm{~h}$.

Table 5: High-dose OC pills available in India

\begin{tabular}{|c|c|c|}
\hline Brand name & Manufacturer & Packaging and cost \\
\hline \multicolumn{3}{|c|}{ High dose Levenorgestrel containing pills (EE 50 mcg and LNG 250 mcg) } \\
\hline DUOLUTON-L & Zydus (G. Rem) & 21 's (106 INR) \\
\hline OVRAL & Wyeth & 21 's (38 INR) \\
\hline \multicolumn{3}{|c|}{ High dose Norgestrel containing pills (EE $50 \mathrm{mcg}$ and NRG $500 \mathrm{mcg}$ ) } \\
\hline OVRAL-G & Wyeth & 21 's (112 INR) \\
\hline VALUECOC-G & Xeno & 21 's (92 INR) \\
\hline EE: Ethinyl Estradiol & & \\
\hline
\end{tabular}

The government of India, through HLL Life Care Limited, has been producing is world's first and only oral non-steroidal contraceptive pill, popularly known as 'Saheli' beginning rom 1991. It contains centchroman (ormeloxifene $30 \mathrm{mg}$ ) is the only non-steroidal pill with nil side effects. Ormeloxifenebelongs to selective estrogen receptor modulators (SERM) which act on the estrogen receptor.

It is free from side effects like weight gain, nausea, vomiting, and headache as it is free from estrogen or progestogen. In rural setup, it is the most popular, convenient and safest mode of contraception with a dosage of one pill a week.

\section{Progestogen-only pills (POPs)}

Progesterone only pill (POP) also known as the mini pill is popular among lactating women as it does not interfere with the breast feeding(table 6). It has certain advantages compared to combined pills as they are safe in conditions like hypertension, history of thromboembolism, where estrogen preparations are contraindicated. The failure rates are slightly high and some women may dislike it as there are chances of irregular bleeding, spotting, mastalgia and abdominal bloating.

Antiepileptic drugs too may interfere with the metabolism of progesterone and may reduce its contraceptive efficacy. The women on POPs are advised to shift to some other forms of contraception if they are on AEDs, but due to some reasons, if a woman wants to continue POP only contraception, the dosage of progesterone may be doubled [24]. Desogestrel is preferred over to levonorgestrel or norgestrel as it can suppress ovulation nearly up to $100 \%[25,26]$. 
Table 6: Lactational pills available in India

\begin{tabular}{lll}
\hline Brand name & Manufacturer & Packaging and cost \\
\hline Progesterone only pills (Desogestrel $\mathbf{7 5} \mathbf{~ m c g )}$ & \\
CERAZETTE & Organon & 75 mcg x 28's (307 INR) \\
DESOGEST & HLL Lifecare & 75 mcg x 28's (223 INR) \\
ZEROGEN & GSK & 75 mcg x 28's (223 INR) \\
\hline
\end{tabular}

\section{Emergency contraceptive pills}

There may be an occasion wherein a woman with epilepsy may come under sexual assault or she might have forgotten to take her regular pills or traditional barrier contraception would have failed. Emergency contraceptive pills contain a very high dose of progestin's and they either act by preventing ovulation or implantation. The available preparations (table 7) mainly contain levenorgestrel which is taken as a single dose of $1.5 \mathrm{mg}$ or $0.75 \mathrm{mg}$ two doses $12 \mathrm{~h}$ apart. The pill should be administered within $3 \mathrm{~d}$ of unprotected intercourse.

It is now known that even emergency contraceptive pills may lose their efficacy on women on AEDs. As such emergency contraceptive pills are associated with higher incidence of ectopic pregnancy and this risk further increase due to decreased efficacy of these drugs due to AEDs [27]. Hence it is recommended to double their dose when prescribed to women on AEDs [28].

Table 7: Emergency contraceptive Pills available in India

\begin{tabular}{|c|c|c|}
\hline Brand name & Manufacturer & Packaging and cost \\
\hline \multicolumn{3}{|c|}{ Post-coital contraception (Two doses of Levenorgestrel $750 \mathrm{mcg}$ ) } \\
\hline 72-HOURS & VHB (Cronus) & $0.75 \mathrm{mg} \times 2$ 's (34 INR) \\
\hline G-PILL & TajPharma & $0.75 \mathrm{mg} \times 2$ 's (44 INR) \\
\hline NORLEVO & Win-medicare & $0.75 \mathrm{mg} \times 2$ 's (46 INR) \\
\hline PILL-72 & Cipla & $0.75 \mathrm{mg} \times 2$ 's (34 INR) \\
\hline \multicolumn{3}{|c|}{ Post-coital contraception (Single dose of Levenorgestrel $1500 \mathrm{mcg}$ ) } \\
\hline I-PILL & Cipla & $1.5 \mathrm{mg} \times 1$ 's $(100 \mathrm{INR}$ \\
\hline SHE-72 tab & Solitaire (CureMax) & $1.5 \mathrm{mg} \times 1$ 's (95 INR) \\
\hline T-PILL-72 & Bestochem & $1.5 \mathrm{mg} \times 1$ 's (69INR) \\
\hline UNPLANNED-72 & Finecure & $1.5 \mathrm{mg} \times 1$ 's (89 INR) \\
\hline UNWANTED-72 & Mankind & $1.5 \mathrm{mg} \times 1$ 's (80 INR) \\
\hline
\end{tabular}

\section{CONCLUSION}

The physician should consider several issues while prescribing contraception for epileptic women. Simultaneous control of seizures and birth event should be kept in mind. Ideally only those AEDs which do not affect hormone metabolism should be considered, however, if at all the woman requires AEDs that may compromise the efficacy of OC pills for better seizure control, then high dose pills containing at least $50 \mathrm{mcg}$ of ethinylestradiol should be prescribed. If a woman is not keen on having 12 cycles in a year, she may be advised to take OC pills continuously with a break after 3 mo so that she will have only 4 cycles in a year, but with highest contraceptive efficacy.

As described earlier, if lamotrigine is the only drug or one of the drugs prescribed for control of seizures, special precautions are necessary. Though switching over to other AEDs is ideal, but this may not be possible in all situations. The dose of lamotrigine may be doubled to maintain steady therapeutic levels, but one should be aware of lamotrigine side effects that can occur during pill free interval and the patient should remember to reduce the lamotrigine dosage during these days. It may be preferable to follow 24-4 regime instead of the traditional 21-7 regime to have withdrawal menses (pill on-pill free days). If this cannot be practiced, the only alternative way is to prescribe depot medroxyprogesterone acetate (Depo-Provera) or levenorgestrel intrauterine device (Mirena), discussion of which is outside the purview of the present article. The professional bodies such as FOGSI (Federation of Obstetrics and Gynaecological Societies of India) should develop guidelines for these issues for improved care of epileptic women.

\section{CONFLICT OF INTERESTS}

\section{Declared none}

\section{REFERENCES}

1. Sridharan R, Murthy BN. Prevalence and pattern of epilepsy in India. Epilepsia 1999;40:631-6.

2. Pennell PB. 2005 AES annual course: evidence used to treat women with epilepsy. Epilepsia 2006;47(Suppl 1):46-53.
3. Reddy DS. The role of neurosteroids in the pathophysiology and treatment of catamenial epilepsy. Epilepsy Res 2009;85:1-30.

4. Sabers A. Pharmacokinetic interactions between contraceptives and antiepileptic drugs. Seizure 2008;17:141-4.

5. Jean-Jacques A. Contraception for women: an evidence based overview. Br Med J 2009;339:563-8.

6. Long L, Montouris G. Knowledge of women's issues and epilepsy (KNOWIE-II): a survey of healthcare professionals. Epilepsy Behav 2005;6:90-3.

7. Shorvon SD, Tallis RC, Wallace HK. Antiepileptic drugs: coprescription of pro convulsant drugs and oral contraceptives: a national study of antiepileptic drug prescribing practice. J Neurol Neurosurg Psychiatry 2002; 72:114-5.

8. Bhat M, Ramesha KN, Nirmala C, Sarma PS, Thomas SV. Knowledge and practice profile of obstetricians regarding epilepsy in women in Kerala state, India. Ann Indian Acad Neurol 2011;14:169-71.

9. Vijayasri S, Archana H, Agrawal A, Hopper W. Computational analysis of interactions between antiepileptic drugs and important placental proteins-a possible route for neural tube defects in humans. Int J Pharm Pharm Sci 2016;8:19-23.

10. Kadam P, Dherai A, Naik P, Lokhande R, Udani V, Gursahani R, et al. Retrospective study on therapeutic drug monitoring of lamotrigine in Indian epileptic patients. Int J Pharm Pharm Sci 2014;6:430-3.

11. Fairgrieve SD, Jackson $M$, Jonas $P$. Population-based, prospective study of the care of women with epilepsy in pregnancy. Br Med J 2000;321:674-5.

12. Harden CL, Leppik I. Optimizing therapy of seizures in women who use oral contraceptives. Neurology 2006;67(Suppl 4):S56-S58.

13. Coulam CB, Annegers JF. Do anticonvulsants reduce the efficacy of oral contraceptives? Epilepsia 1979;20:519-25.

14. Crawford P, Chadwick DJ, Martin C, Tjia J, Back DJ, Orme M. The interaction of phenytoin and carbamazepine with combined oral contraceptive steroids. Br J Clin Pharmacol 1990;30:892-6.

15. Wilbur K, Ensom MHH. Pharmacokinetic drug interactions between oral contraceptives and second-generation anticonvulsants. Clin Pharmacokinet 2000;38:355-65. 
16. Perucca E. Clinically relevant drug interactions with antiepileptic drugs. Br J Clin Pharmacol 2006;61:246-55.

17. Miners JO, Mackenzie PI. Drug glucuronidation in humans. Pharmacol Ther 1991;51:347-69.

18. Sabers A, Ohman I, Christensen J, Tomson T. Oral contraceptives reduce lamotrigine plasma levels. Neurology 2003;61:570-1.

19. Hachad H, Ragueneau-Majlessi I, Levy RH. New antiepileptic drugs: a review on drug interactions. Ther Drug Monit 2002;24:91-103.

20. Sabers A, Buchholt JM, Uldall P, Hansen EL. Lamotrigine plasma levels reduced by oral contraceptives. Epilepsy Res 2001; 47:151-4.

21. Sidhu J, Job S, Singh S, Philipson R. The pharmacokinetic and pharmacodynamic consequences of the coadministration of lamotrigine and a combined oral contraceptive in healthy female subjects. $\mathrm{Br} \mathrm{J}$ Clin Pharmacol 2006;61:191-9.

22. Schwenkhagen AM, Stodieck SR. Which contraception for women with epilepsy? Seizure 2008;17:145-50.
23. Reddy DS. Clinical pharmacokinetic interactions between antiepileptic drugs and hormonal contraceptives. Expert Rev Clin Pharmacol 2010;3:183-92.

24. O'brien MD, Guillebaud J. Contraception for women taking antiepileptic drugs. J Fam Plann Reprod Health Care 2010;36:239-42.

25. Rice C, Killick S, Dieben T, CoelinghBennink H. A comparison of the inhibition of ovulation achieved by desogestrel $75 \mathrm{mcg}$ and levonorgestrel 30 mcg daily. Hum Reprod 1999;14:982-5.

26. O'brien MD, Guillebaud J. Contraception for women with epilepsy. Epilepsia 2006;47:1419-22.

27. Rajesh B, Neelam P, Laxman B, Nirajan B, Buddha BB, Bidur S. To determine the risk factors associated with ectopic pregnancy. Asian J Pharm Clin Res 2015;8:93-7.

28. O'Connor SE, Zupanc ML. Women and epilepsy. J Pediatr Pharmacol Ther 2009;14:212-20.

\section{How to cite this article}

- Shripad Hebbar. Epilepsy and oral hormonal contraceptionIndian perspective. Int J Pharm Pharm Sci 2017;9(3):01-06. 